\title{
Rural Accessibility and Distribution of Social-Services in Ise-Orun Local Government Areas of Ekiti State, Nigeria
}

\author{
Ale Adeniyi Samuel, Fatusin Afolabi Frances \\ Department of Geography and Planning Sciences, Adekunle Ajasin University, Akingba Akoko, Nigeria \\ Email address: \\ alesamniyi@yahoo.com (A. A. Samuel), fatusinafolabi@gmail.com (F. A. Frances) \\ To cite this article: \\ Ale Adeniyi Samuel, Fatusin Afolabi Frances. Rural Accessibility and Distribution of Social-Services in Ise-Orun Local Government Areas \\ of Ekiti State, Nigeria. Humanities and Social Sciences. Vol. 6, No. 4, 2018, pp. 103-108. doi: 10.11648/j.hss.20180604.11
}

Received: January 29, 2018; Accepted: May 3, 2018; Published: July 25, 2018

\begin{abstract}
This paper examined rural accessibility and distribution of public facilities in ise-orun local government areas of Ekiti State, Nigeria. Purposive sampling techniques were used to select 5 sampled rural settlements in the study area during reconnaissance survey while random sampling method was used to select one hundred and fifteen (150) adult respondents in the study area. The data collected were subjected to both descriptive and inferential statistical analyses. Chi-square statistical analysis was employed to test the significance of the stated hypothesis at $\alpha=0.05$. it was discovered that the calculated Chisquare value of 9.28 is lesser than the tabulated value (18.31), therefore the null hypothesis is rejected, while the alternative hypothesis is accepted. Meaning that road accessibility has great influence on spatial distribution of social infrastructure in the study area. In this wise the paper recommends that provision of basic infrastructural facilities such as well accessible roads, pipe borne water and electricity among others, should be given priority to further aids the growth of the rural areas for better rural sustainability and development of Ise-Orun LGAs.
\end{abstract}

Keywords: Access, Mobility, Social- Services, Rural and Sustainability

\section{Introduction}

Over the years, Accessibility and mobility plays a vital and significant role in the socio-economic and political development of a nation whether developed, developing or underdeveloped. Therefore provision of access and mobility is essential for the efficient organization and functioning of any society either rural or urban [1]. Aderamo and Magaji 2010 and [2] Aloba (1986). As a society grows in terms of population and functions, the need for interaction among its various components also increases thereby requiring quality and effective mobility/ transport system to access their immediate needs. On this note accessibility and mobility constitutes an avenue through which different parts of the society are linked together [3, 4] Ikporukpo 1987and Ogunsanya 1987). As noted by [1] Aderamo and Magaji 2010 in Munby "there is no escape from transport even in the most remote and least developed of inhabited regions".

In expression of an individual's free will, mobility takes place with a view to reaching and satisfying such individual's socio-economic, cultural and political needs in different places. For instance, trips to work, schools, postal services, recreations, health centres, relatives, shops/markets and banks are undertaken in order to procure these services, which are available in specific locations. The frequency, pattern, form, structure and complexity of the trips to these services are usually influenced and constrained by physical demographic, cultural and socio-economic factors. [5] (Boarnet and Randall, 2001). However, [1-4] Aloba (1986), Ikporukpo (1987). Ogunsanya (1987). Aderamo and Magaji (2010) in their various and independent studies revealed that accessibility and mobility to infrastructures are essential and critical to rural-welfare, the development of rural road network also deemed critical and fundamental to rural improvement.

Although this described the tendency of positive effects on the economy of any nation with increase in the distribution of her socio-economic and transport infrastructure over-space. From the foregoing, improvement in whole rural environment may as well induce an increase in the supply of transport and other infrastructural facilities, which may also influence the development of rural settlements and large market as well as reducing poverty level of rural people by allowing the basic necessity of life such as health care 
delivery, education, postal services and market to be more accessible to the rural dwellers. [6] (Ale, 2013). Mobility and accessibility is inevitable for effective socio-economic interaction, cultural integration and overall regional development of the built environment.

However, [7] Ogunsanya (1988) identified a strong relationship between mobility, underdevelopment and rurality. He argued that the greater the degree of rurality, the lower the level of transport development. These consequently have been responsible for low transport development in rural areas of Nigeria which houses over 70 per cent of the nation's population. Efforts have, however, been made in recent times to address the rural accessibility problem in the country in order to proffer solutions to the identified challenges. The Association of Local Government of Nigeria (ALGON) recently initiated a proposal to the Federal Government that would boost rural accessibility in the country [8] (Adeyanju 2009). To actualize this, a tripartite arrangement between the 774 local government areas of the federation, the federal government, and private transport sector operators were put in place to ease rural transportation and accessibility challenges in the country.

Investments on the transportation sector, are not only aimed at increasing the level of interaction but also to improve rural accessibility particularly as it relates to accessibility to the various public facilities that are located at different parts in the rural landscape. The major problem with the pattern of distribution of public facilities in Nigeria however, is that, it exhibits an urban bias instead of a rural locational patterns which further helps to increase rural poverty. For example, some areas are heavily served with public facilities such as health centres, schools, electricity, Pipe born-water, postal services and market among others, while some areas are either underserved or not served at all [1] ( Ikporukpo 1987). Another problem with the distribution of public facilities in Nigeria particularly in the rural areas, is the lack of coordination in the distribution of these facilities so as to make them more useful to the population.

According to [2, 9 and 10] Aloba (1986), ogunsanya (2002) and Ogunbodede (2010), in their individual studies recognised the role of transport in the overall development of any society and the desire to promote rapid socio-economic development particularly in the rural areas; the federal, state and local governments in Nigeria have been working towards the improvement and development of transportation system in the country. In the first, second, third and fourth National Development plans, $19 \%, 23 \%, 22 \%$ and $15 \%$ of the total capital outlay went to the transport sector respectively [11] (Adeyemi 2001). These investments on the transportation sector, are not only aimed at increasing the level of ruralurban movement but also to improve rural-urban accessibility particularly as it relates to accessibility of rural people to the various public facilities that are located at different parts in the rural landscape.

The objectives of this study is to assess the spatial distribution of social services (public facilities) in Ise-Orun Local Govt Area, examine the mobility constrain to access the distributed social facilities in the study area and finally to examined the condition and the adequacy of the social services in the Local Government Area with a view to ameliorating the situation.

\section{Concept of Rural Development}

The concept of rural development means various things to various scholars. According to [12] Handy and clifton (2001), rural development is a multidimensional process that involved the acceleration of economic growth, the reduction of inequality and eradication of absolute poverty among the rural inhabitants. [13] Onokerhoraye (1985) in his opinion, noted that, it is the improvement in the general overall in per capital Gross National Production (GNP) passed down to the grass root inform of economic opportunities that create the necessary conditions for the growth of the people in the rural are. However, [14] Udoh (1975), in his studies observed that, improvement in the development within the rural settlement is beyond the level of per capital income or standard of living but it also depends on the complexity of some factors such as food, health, education and recreation among others. From the foregoing, the means to improve rural development is to strengthening the capacity increase, expansion and modernization of existing rural transport facilities as well as introduction of new technology to movement patterns within the rural environment[15] (Ale 2014).

\section{Accessibility and Mobility Challenges}

Poor mobility and accessibility in the rural areas poses a great challenge to rural development efforts in Nigeria as it has continued to make most of the rural areas isolated from the main stream of the modern societies [2 and 6](Aloba 1986 and Ale 2013 ). This has resulted in low provision of social infrastructural facilities, low productivity, low income and a fall in the standard of living of rural residents as well as high rate of poverty among others. The rate of poverty in most rural communities in Nigeria has progressively increased over the years. Poverty is at a higher level in the rural areas in Nigeria than in the urban areas.

In 1980 , the poverty level of the rural dwellers was put to be $29.3 \%$; in 1985 it went up to $51.4 \%$ and in 1992 the figure came down to $46.1 \%$ while in 1996 , the rural population in poverty had increased to $69 \%$. In respect of urban areas, poverty levels were $17.6 \%$ in $1980,37.8 \%$ in $1985 ; 37.5 \%$ in 1992 and 55.5\% in 1996 respectively [16] (FOS 1999). [17] Adesanya et al. (2000) had observed that, rural travel and transport in most rural areas in Nigeria still take place with great difficulties thereby compounding and worsening the problem of rural productivity and rural poverty.

Several studies have been conducted on the nature and characteristics of rural roads which lead to the problems of rural accessibility.[18] Adeniji (1983) identified the problem of low volumes of traffic on rural roads coupled with periodic variations and sharp seasonality in the demand for transport as factors which contribute to the apparent neglect 
of roads in the rural areas by most of the state governments in Nigeria. [4 and 19] Ogunsanya (1987) and Filani (1993) found in their different studies that where motorable roads exist in rural areas, in Nigeria, they are mostly of unpaved surface, narrow width, circuitous alignment and with low quality bridges. In most cases, they are either clad with potholes or characterised by depressions and sagging. Such unsurfaced roads are hardly passable during the rainy season when vehicles get stuck in mud or when the improvised bridges of cut-free trunks get swept away by flood.

As noted by [17] Adesanyan (2000) there is a strong relationship between transportation, underdevelopment and rurality. He stressed that, the greater the degree of rurality, the lower the level of transport development. These consequently have been responsible for low transport development in depressed areas of Nigeria which houses 70 per cent of the nation's population. Efforts have however been made in recent times to address the rural transport problem in the country in order to proffer solutions. The Association of Local Governments of Nigeria (ALGON) recently initiated a proposal to the Federal Government that would boost rural transportation in the country [8] (Adeyanju 2009). To actualize this, a tripartite arrangement between the country's 774 local governments, the federal government, and private sector operators were put in place to ease rural transportation in the country. Also, the Federal Government through the Federal Ministry of Agriculture and Water Resources adopted the Rural Travel and Transport Program (RTTP) of the Sub-Sahara Africa Transport program (SSATP) in 1999 with a view to a framework for the improvement of an efficient transportation system for the rural dwellers as well as improve on their quality of life. It is however discovered that, transport is an important instrument for correcting spatial distortions facilities both in the developed and in developing nations of the world.

In many cases, the objective of transport infrastructure investment is to improve the accessibility of a given region by reducing travel time or increasing the potential to travel. Accessibility can be measured as the quantity of economic or social activities that can be reached using the transport system. Improvement in accessibility can also increase the market size for manufacturing, tourism and labour, as well as leading to increased competition and decentralization of activities. However, the impact of efficient transport services in a region could be either positive or negative, depending on its initial level of competitiveness.

\section{Study Area}

Ise-Orun Local Government Area is the study area, with the Headquarters of the Local Government is located in Ise Ekiti in Ekiti State. The study area is about 56 sq. km. Absolutely, it lies between latitude $7^{\circ} 20^{1}$ and $7^{\circ} 31^{1}$ North of the equator and between longitude $5^{\circ} 21^{1}$ and $5^{0} 31^{1}$ East of the Green-wich meridian. Relatively, the study area is bounded in the East by Emure Local Government Area in
Ekiti State, to the West by Ikere Local Government Area of Ekiti State, to the North and South by Ado-Ekiti and Gboyin Local Government all in Ekiti State, as well as Ijare in Akure North Local Government Area of Ondo State respectively.

The study area has a total population of 98,467 people (2006 Population census). In general, the area is located on a fairly undulating low land except some doted isolated hill known as Iganmode hill and a ridge that stretch to the northern part of the study area. This gives room for easy construction of access route to promote easy movement of people, goods and services most importantly food and cash crops to the market. The main mode of transport in the study area is basically road transport. The Local Government has both intra-rural and inter-rural roads network. The inter rural roads are tarred and maintained by the state government while the villages and the farmsteads are mostly linked with graded and un-tarred roads. These are the roads maintained both by the local government and through community efforts although some of these routes are conventional in nature.

\section{Materials and Methods}

Purposive sampling techniques were used to select five (5) rural settlements in the study area during reconnaissance survey while random sampling method was used to select one hundred and fifteen (115) adult respondents in the five selected settlements. Data used for the study were obtained from both primary and secondary source. For primary data, questionnaire was administered in the selected settlements in the study area. In so doing 150 copies of questionnaire were purposively administered to the adult household heads both male and female respondents in the study area. However, the entire One hundred and fifteen copies of the questionnaire were duly returned. The settlements include Bolorunduro, Obada, AbaUso, Ogbese and Aba-Oyo. The questions addressed issues that bordered on socio- economic status of the respondents, nature and quality of roads, road characteristics, mode of access and available modal choice others are questions bordered on distribution of public facilities, types of public infrastructure available in the area as well as accessibility and mobility constraint to access the various public services in the study area. The secondary data were sources from text-books, journal, maps and magazines. The null hypotheses was tested at $(\mathrm{P}=0.05)$ using the data collected on the field, however, the data collected were subjected to both descriptive and inferential statistical analyses to arrive at some conclusion discussed in the latter part of the paper to determine the significance of road accessibility on distribution of public facilities in the study area:

Ho: Road condition has no significant influence on the distribution of public facilities in the study area.

\section{Findings and Discussion}

Socio-economic status of the respondent 
Data on the socio- economic status of the respondents were analyzed and shown in the table below.

Table 1. Socio-economic status of the respondent.

\begin{tabular}{lll}
\hline Bio- Data & Options & Percentage \\
\hline \multirow{2}{*}{ Sex } & Male & 63 \\
& Female & 52 \\
Age & 25-35 year & 18 \\
& 36-59 Year & 57 \\
\multirow{4}{*}{ Marital Status } & $>60$ & 40 \\
& Single & 27 \\
& Married & 70 \\
Occupation & Widow/Widower/Divorce & 18 \\
& Farming & 84 \\
& Civil Servant & 05 \\
& Trading & 10 \\
\hline
\end{tabular}

Source; field Survey; 2014.

From the table, it was discovered that $63 \%$ of the respondents were male adults while the remaining $37 \%$ of the respondents were female. In terms of age, it was discovered that $18 \%$ of the respondents were between the ages of 25-35 years old. The highest proportions of the age of the respondents fall between the age bracket of 36 and 59 years old while only $12 \%$ of the respondents were elderly people. In the same vein, it was discovered that $70 \%$ of the respondents were married with only $27 \%$ of the respondents were still single and the remaining $18 \%$ were either widow or divorcee. The occupation of the respondents were also analyzes and it was discovered that higher percentage of the respondents were farmers and only 5\% of the respondents were civil servants while $10 \%$ and $16 \%$ of the respondents were into trading and vocational. This signifies that larger proportion of the respondents engaged in farming activities.

Availability of Public Facilities in the Study Area.

The level of availability of public facilities (infrastructure) in the selected areas was determined using By- polar adjectives of 1 for Presence and 0 for Not-Presence. However this was carried out by the respondent's responses during the administration of the questionnaire.

Table 2. Public facilities in the Study Area.

\begin{tabular}{|c|c|c|c|c|c|c|}
\hline \multirow{2}{*}{ Available facility } & \multicolumn{6}{|c|}{ Selected Settlement } \\
\hline & Aba-Oyo & Aba-Uso, & Bolorunduro & Obada & Ogbese & Total \\
\hline Electricity & 1 & 0 & 1 & 1 & 1 & 04 \\
\hline Health Centre & 1 & 0 & 1 & 1 & 1 & 04 \\
\hline Market & 1 & 0 & 0 & 1 & 1 & 03 \\
\hline Road & 0 & 0 & 1 & 1 & 1 & 03 \\
\hline Bore hole & 1 & 1 & 1 & 1 & 1 & 05 \\
\hline School (i) Primary & 0 & 0 & 1 & 1 & 1 & 03 \\
\hline Recreation centre & 0 & 0 & 0 & 1 & 0 & 01 \\
\hline Hall & 0 & 0 & 0 & 0 & 0 & 0 \\
\hline Drainages/Culverts & 0 & 0 & 0 & 1 & 0 & 01 \\
\hline Church/mosque & 1 & 0 & 1 & 1 & 1 & 04 \\
\hline Total & 05 & 01 & 06 & 10 & 07 & 29 \\
\hline
\end{tabular}

Source; Field survey 2014.

From the table, it shows that only $80 \%$ of the sampled rural settlements in the study area have electricity supply, health and religion centres (i.e Aba-Oyo, Bolorunduro, Obada and Ogbese). This is so because the rural settlements are very close to the main road that link major towns together or located very close to the main grid-line of electricity. However, observation from the field shows that most of the facilities were sited at these points by the government for political reasons. While the remaining 20\% (Aba-Uso) have no access to such facilities, simply because the location of such settlements were favourable.

Similarly, it was observed from the table that the presence of borehole is common to all the sampled settlements. This simply suggested that borehole were adequately distributed which has helped in solving the problem of scarcity and shortage of water supply in the study area. In the same vein, the sampled rural settlements were not well covered with accessible roads except two or three settlements that were located along the artery routes that linked the main towns in the study area. The only identified routes in the selected areas were the untirred feeder roads and these routes are characterized by pot-holes, dust during the dry season while some part of the roads and seriously eaten up by erosion which makes mobility difficult both in the dry and rainy seasons. However, this has led to in effective distribution of social infrastructural facilities in the area. Hence, high cost of transport, lost in man's hour, wastage in farm produce and low agricultural product in the study areas. Thus one can succinctly concludes that a well accessible road network has great influence on farm production and well distribution of public facilities over space. This observation gave credence to the observation of [20, 7, 6 and 15] Aloba (1987), Ogunsanya (1998) and Ale (2013 and 2014) that there is clear evidence between improved road network and rural development.

More so, recreation centres, hall for social events and good drainage system as well as schools were not adequately provided for the rural residence as part of the infrastructure require for rural development and sustainability. From the table, $80-100 \%$ of the sampled settlements were devoid of 
recreational facilities, event centres for social, political and community events, good drainage system and basic education. While only $60 \%$ of the selected settlement have access to a few facility like; market, road and primary schools however, this has negative impacts on the objectives of the millennium development goal programe put forward by the United Nation. From the table, one can easily assert that in the study area, almost all the settlements have access to a religious centre or the other.
In other to ascertain the significance influence of road on the spatial distribution of public facilities in the rural areas in Ise - Orun Local Government, table 3 was subjected to ChiSquare Statistical Analysis and the summary of this analysis is as shown in table 4.

Testing of the stated hypothesis Ho: Road condition has no significance influence on the distribution and adequacy of public social services in the study area;

Table 3. Distribution of Public Facilities in the study area.

\begin{tabular}{ll}
\hline Facility & Total Available \\
\hline Electricity & 04 \\
Health Centre & 04 \\
Market & 03 \\
Road & 03 \\
Bore hole & 05 \\
School (i)Primary & 03 \\
(ii) Sec & 01 \\
Recreation centre & 01 \\
Hall & 0 \\
Drainages/Culverts & 01 \\
Church/mosque & 04 \\
\hline
\end{tabular}

Source: field Survey 2014.

Table.4. Summary of chi-square analysis

\begin{tabular}{llllll}
\hline Variables & $\mathbf{d} / \mathbf{f}$ & Level of significance & Calculated $\mathbf{X}^{2}$ Value & Tabulated value & Decision \\
& $(\mathrm{n}-1)(\mathrm{n}-1)=(11-1(2-1)=10$ & .05 or $5 \%$ & 9.28 & 18.31 & $\begin{array}{l}\mathrm{H}_{\mathrm{o}} \text { is rejected While the alternative } \\
\text { hypothesis }\left(\mathrm{H}_{1}\right) \text { is accepted }\end{array}$ \\
\hline
\end{tabular}

Source: Computer printout, 2014.

From the table, it was vividly shown that at ten (10) degree of freedom and at 5\% significant level of confidence, the computed Chi-square value was 9.28 is lesser than the tabulated

Value of 18.31. Since the calculated Chi-square value of 9.28 is lesser than the tabulated value (18.31), the null hypothesis is rejected, while the alternative hypothesis is accepted. Meaning that road accessibility has great influence on spatial distribution of social infrastructure in the study area.

\section{Conclusion}

The impact of accessible roads in the rural areas in Nigeria cannot be overemphasized. However, the study examined the impact of accessibility on the spatial distribution of public facilities in the rural areas of Ise-Orun Local government Area, the study revealed that, most of the rural areas in Nigeria are not plan for by the governments knowing fully well the role of rural areas in a nation's economic development in terms of food and raw material production. Also, the subjective notion of the rural people need to be considered when development programs are being put in place so that the rural populace are not considered third class citizen of the nation

Also government should set machineries on motion to monitor proper implementation and execution of projects and programs put in place by governments to enhance or improve the condition and standard of living of the rural dwellers. In the same vein, the rural people need to be well guided, tutor and or oriented on maintenance culture of public properties.

\section{References}

[1] Aderamo A. J. and Magaji S. A. (2010); Rural Transportation and the Distribution of Public Facilities in Nigeria: A Case of Edu Local Government Area of Kwara State Journal of Human Ecology, 29 (3): 171-179.

[2] Aloba, O. (1986); Rural Transportation In: I Falola, SA Olarewaju (Eds.): Transport Systems in Nigeria. Syracuse University, Maxwell School of Citizenship and Public Affairs. Series XLII: 125-138.

[3] Ikporukpo, C. O (1987); An Analysis of the Accessibility of Public Facilities in Nigeria. Socio-economic Planning Sciences, 21(1): pp $61-69$.

[4] Ogunsanya, A. A (1987); Rural Accessibility Problems and Human Resources Development: Case study from Nigeria. Journal of Rural Studies. Vol. 3 No.1 pp 31-42.

[5] Boarnet, M. G and C Randall (2001); Travel by Design: The Influence of Urban form on Travel. New York: Oxford University Press.

[6] Ale, A. S (2013); Rural Transportation and food crop production in Akokok South Local. Government Area of ondo State, Nigeria. Journal of Environment. Vol. 02. issue 5 pp 112. 
[7] Ogunsanya. A. A (1988); A Case for Rural Transport Policy in Nigeria. A memorandum submitted to the Committee of Experts on National Transport Policy for Nigeria in Year 2000. Abuja: Federal Ministry of Transport.

[8] Adeyanju, D. (2009); Meltdown: Local Governments Partner Federal Government, Private Sector Operators to Ease Rural Transportation. The Nation, May 6, 2009, P. 12.

[9] Ogunsanya, A. A (2002); Maker and Breaker of Cities. 59 $9^{\text {th }}$ Inaugural Lecture Presented in the University of Ilorin, Nigeria, on $27^{\text {th }}$ june, 2002.

[10] Ogunbodede, E. F (2010); Cell Phone Usage and Travel Behavour in Ondo State, Nigerian Journal of Mobile Communication Vol. 4 No 3. pp 68-74.

[11] Adeyemi O (2001); Moving Nigeria Forward: The Development Planning Approach. Ibadan: University of Ibadan Press.

[12] Handy, S. L. and K. J. Clifton (2001); "Local Shopping as a Strategy for reducing Automobile Travel," Transportation, Vol. 28, No. 4, PP 317-346.

[13] Onokerhoraye. A. G (1985); An Outline of Human Geography, Benin Geography and Planning Series, Eguavoen Printers.
[14] Udoh R. B (1975); Migrant Tenant Farmers of Nigeria African University Press.

[15] Ale. A (2014); Graph Measurement of Road Network Connectivity \&Accessibility on Farming Activities in Akoko South-West LGAs of Ondo State, Ngeria. International Journal of Innovation and Applied Studies. Vol. 9. No. 3 pp 1258-1265.

[16] Federal Office of Statistics (1999); Poverty Profile for Nigeria. 1980 - 1996. Lagos: FOS.

[17] Adesanya, A, Philips AO, Titilayo S. T (2000); Transportation Development in Nigeria in 2010 Ibadan: Nigerian Institute of Social and Economic Research (NISER).

[18] Adeniji, K (1983); "Transport Subsidies in Nigeria" $A$ synopsis of workshop proceedings, NISER, Ibadan and FEF, Germany.

[19] Filani, M. O (1993); Transport and Rural Development in Nigeria. Journal of Transport Geography, 1: 248- 254.

[20] Aloba, O (1987); The Spatial Evolution of settlements and the Rural Transport Network in Ile-Ife Division. In Environment and Spatial Factor in Rural Development in Nigeria. Proceeding of the $20^{\text {th }}$ Annual Conference of the Nigerian Geographical Association. University of Ile-Ife. 